\title{
Phytochemicals and functional foods. Current situation and prospect for developing countries
}

Evelyn B. Rodriguez ${ }^{1}$, Maxima E. Flavier ${ }^{1}$, Delia B. Rodriguez-Amaya² and Jaime Amaya-Farfán ${ }^{2}$

This review updates and attempts to present the complex panorama of bioactive phytochemicals and functional foods. For such purpose and given the breadth of the field, it was necessary to survey a large volume of scientific literature. The different types of studies used to provide evidence for efficacy are described. The different groups of health-promoting substances (carotenoids, phenolic compounds, phytosterols and phytostanols, tocotrienols, organosulfur compounds, nondigestible carbohydrates) are presented with a discussion of the dietary sources and the chemical and biological properties that explain their modes of action. Functional foods of plant origin (broccoli and other cruciferous vegetables, oat, flaxseed, tomato, soybean, citrus, berries, tea, grapes and wine, garlic) are discussed in terms of their health effects, the phytochemicals responsible and the body of evidence supporting such effects. The review emphasizes the importance of consuming fruits and vegetables for the general state of health of the population and points out some technical and scientific opportunities that can be explored in developing countries.

Keywords: functional foods, phytochemicals, fruits and vegetables, health promotion, healthy eating, degenerative diseases

\section{Substâncias fitoquímicas e alimentos funcionais. Situação atual a perspectivas para países emergentes.}

Esta revisão atualiza e tenta apresentar o panorama complexo de fitoquímicos bioativos e alimentos funcionais. Neste contexto e considerando a amplitude do assunto, foi necessário relacionar um vasto volume de literatura científica. São descritos os diferentes tipos de estudos utilizados para obter evidência de eficácia. Os diferentes grupos de substâncias que promovem saúde (carotenóides, compostos fenólicos, fitoesteróis e fitoestanóis, tocotrienóis, compostos organosulfurados, carboidratos não digeríveis) estão apresentados com uma discussão das fontes alimentícias e das propriedades químicas e biológicas que explicam os seus modos de ação. Alimentos funcionais de origem vegetal (brócoli e crucíferas, aveia, linhaça, tomate, soja, citrus, amoras, chá, uva e vinho, alho) estão discutidos em termos dos seus efeitos na saúde, dos fitoquímicos responsáveis e o conjunto de evidências que apóia tais efeitos. A revisão enfatiza a importância de consumir frutas e hortaliças para o estado geral de saúde da população e aponta oportunidades técnicas e científicas que podem ser exploradas nos países em desenvolvimento.

Palavras-chave: alimentos funcionais, fitoquímicos, frutas, hortaliças, alimentação saudável, promoção da saúde, doenças degenerativas.

${ }^{1}$ Institute of Chemistry, University of the Philippines at Los Baños, College, Laguna 4031, Philippines

${ }^{2}$ Faculty of Food Engineering and Center for Food Security Studies - NEPA, State University of Campinas, C.P. 6121, 13083-862 Campinas, SP, 


\section{Introduction}

The new concept of functional foods raises concerns about food security and the proper selection of an adequate diet, beyond the classical adequacy in energy, protein, essential fats, vitamins and minerals. Today, it is recognized that foods not only provide basic nutrition, but can also prevent diseases and ensure good health and longevity. This concept is not new to people in some parts of Asia - they have always believed that certain foods are beneficial to health and some even therapeutic. But these beliefs were primarily anecdotal, based on centuries of tradition and largely lacking scientific bases.

Various terms have been used interchangeably to designate foods for disease prevention and health promotion. Designer foods, coined in 1989, is used to describe foods that naturally contain or are enriched with nonnutritive, biologically active chemical components of plants that are effective in reducing cancer risk (Caragay, 1992). Nutracenticals was introduced also in 1989 by the U. S. Foundation for Innovation in Medicine to refer to "any substance that is a food or a part of a food and provides medical or health benefits, including the prevention and treatment of disease" (DeFelice, 1995). In 1994, the U. S. Institute of Medicine's Food and Nutrition Board defined functional foods as "any food or food ingredient that may provide a health benefit beyond the traditional nutrients it contains" (Thomas and Earl, 1994).

Several factors - scientific advances, consumer demand, increasing health care costs, an aging population, technical advances in the food industry, and changing regulatory environment - have stimulated the field of functional foods (Hasler, 1996). Scientific investigations have resulted in the accumulation of scientific evidence supporting the vital role of diet in overall health and well-being. For instance, six of the ten leading causes of death in the United States - cancer, coronary heart disease, stroke, diabetes, atherosclerosis, and liver disease - have been increasingly shown to be related to diet.

\section{The Scientific Evidence for Efficacy}

A convincing scientific relationship between food and its health effects can be established by using the following methods of investigation: epidemiological studies, biological and experimental studies, and intervention trials. No single study design can stand on its own. Corroborative findings from different types of studies are needed to form a solid basis for recommendations designed to improve public health (World Cancer Research Fund, 1997).

Epidemiology examines the correlation of a dietary constituent to an outcome, but does not demonstrate a cause-and-effect relationship. There are several types: intercountry and intracountry correlations (ecological), time-trend and migrant studies, case-control (retrospective) studies, and cohort (prospective) studies (Clydesdale, 1996; World Cancer Research Fund, 1997).

Correlation or ecological study is the simplest type of study for exploring the relationship between a diet and a disease (e.g. cancer). Carried out at the population level, it involves comparison of disease incidence rates with consumption of a food or a food component or other aspects of the diet. An obvious limitation of this study is that, while it may suggest a relationship between a specific environmental factor (e.g. an aspect of diet) and disease, the actual relationship may be with a different diet-associated confounding factor. Moreover, a lack of correlation between an aspect of diet and disease may disguise an actual relationship, due to possible varying genetic predisposition in different populations. Thus, false-positive or falsenegative results may be obtained. Despite these limitations, correlation studies have special strengths, particularly when conducted between populations either internationally or cross-culturally among contrasting populations within a country.

Migrant studies allow the assessment of whether the correlations observed in ecological studies are due to genetic or environmental factors. For example, populations migrating between areas with different cancer incidence rates acquire the characteristic of their new locations for most cancers, often after only one or two generations. Such findings show that genetic factors are not primarily responsible for the large difference in cancer rates in different regions and countries. Cancers whose incidence shifts with migration are diseases with environmental causes, and migrant studies are very important for establishing the environmental causes of such diseases.

$$
\text { In case-control (retrospective) studies, a group of }
$$


individuals with the disease (case) is compared with a group without the disease (control) with regard to a possible risk factor (e.g. diet). Many of the weaknesses of correlation studies can be avoided in case-control studies by eliminating known or suspected confounding factors from the study design or controlling them in the data analysis. Dietary habits before the onset of the disease are assessed retrospectively by questionnaire or interview. Thus, the major drawback of this study is the heavy dependence on subject recall. Cases and controls may differ in the accuracy of recalling their previous diets so that ensuing comparisons may be biased.

Recall problems and bias are avoided in cohort (prospective) studies. Dietary information is collected from a large population, free of the disease at the beginning of the study, and these individuals are followed through time, usually for a decade or more, until a sufficient number of participants develop the disease. The relationship of the incidence of the disease to specific characteristics of individual diets is then analyzed. Cohort studies allow repeated assessments of diets at regular intervals, examination of the effects of diet on the disease in question as well as other diseases, and collection and storage of tissue samples for subsequent analysis. However, they take a long time, require a large number of subjects and are very expensive.

Certain important associations can be missed in an epidemiological study if it is not sufficiently large because of the inadequate statistical power of the study. To circumvent this problem, the technique of meta-analysis, which statistically summarizes the results of a collection of studies, is used. Meta-analysis may select only prospective studies, or studies judged to be of high quality. But, unless it includes all relevant studies from a systematic literature review using fairly objective criteria for selection, it can repeat or even magnify the bias of individual studies.

Biological and experimental studies can be carried out on humans or animals or on human, animal or microbial materials or cell cultures. Unlike most epidemiological studies, this type of study entails more than observations - the scientist controls the system under investigation, makes measured interventions in different subsets of the study populations and compares the outcome between those subsets. To obtain meaningful scientific data, it may be necessary to develop surrogate markers or disease endpoints that have a predictive value in establishing a causeand-effect relationship with a disease (Clydesdale 1996). Examples of well-accepted markers are oral leukoplakia in oral cancer, adenomatous colon polyps in colon cancer, and circulating lipids in heart disease. Overall, epidemiology backed by convincing experimental and biological findings can provide strong causal relationship between diet and disease. This evidence for a causal relationship is further strengthened when a biologically plausible mechanism of action of the constituents of the diet is identified (World Cancer Research Fund, 1997).

Because of access to body tissues and more accurate control of laboratory conditions, more detailed mechanistic information on the action of a dietary component or food can be derived from animal rather than human studies. However, these results must be validated in humans as it is widely acknowledged that animal models may not physiologically represent humans.

Likewise, effects observed with in vitro systems must be interpreted carefully since these systems, though attractive for their simplicity, may not reflect the intricacies of the numerous reactions/processes and interactions that occur simultaneously in the human body.

In intervention trials, a control group of individuals is given an inactive substance, and an intervention group is given dietary constituents that may affect disease risk. This study is somewhat similar to trials used to test drugs. The preferred experimental design is the randomized controlled trial in which people are assigned to an intervention or control group at random. The strength of evidence obtained is increased if the study is conducted 'blind', i.e., the subjects do not know whether they belong to the control or intervention group, or 'double-blind', i.e., the investigators do not know either. These trials usually test the effects of specified levels of supplementation with dietary constituents (as pills, capsules or other forms).

Intervention trials are also subject to certain limitations. The time between the change in the level of a dietary factor and expected change in the incidence of the disease is usually uncertain, thus the trials should be of long duration. Since these 
trials are based on epidemiological studies that have shown protective effects of a group of foods, there is always the possibility that the actual active agent or combination of agents in the foods may not be those actually employed in the trial. Also, the agents used may have a protective effect while contained in foods, but may have unexpected effects in isolation, especially in doses higher than those found in normal diets.

\section{Bioactive Food Phytochemicals}

Plant foods contain many bioactive compounds in addition to those which are traditionally considered as nutrients, such as vitamins and minerals. These physiologically active compounds, referred to simply as 'phytochemicals', are produced via secondary metabolism in relatively small amounts. Until fairly recently, they have been generally assumed to be irrelevant, sometimes even harmful, to human health.

The number of identified phytochemicals has increased dramatically in the last decade. Some groups of phytochemicals which have or appear to have significant health potentials are: carotenoids, phenolic compounds (flavonoids, phytoestrogens, phenolic acids), phytosterols and phytostanols, tocotrienols, organosulfur compounds (allium compounds and glucosinolates), and nondigestible carbohydrates (dietary fiber and prebiotics).

\section{Carotenoids}

Among the phytochemicals, carotenoids have been the most studied. Carotenoids are tetraterpenoids responsible for the yellow, orange and red color of many fruits, vegetables, a few roots, egg yolk, fish like salmon and trout, crustaceans. They are synthesized by plants, algae, fungi, yeasts and bacteria, but are merely accumulated from the diet, unchanged or slightly modified, in some animals.

In foods, about a hundred carotenoids have been found. Typically a food would have one to five major carotenoids with a series of minor carotenoids in trace or very small amounts. The principal carotenoids encountered in human blood and are the most investigated in terms of human health are: $\beta$-carotene, $\alpha$-carotene, $\beta$-cryptoxanthin, lutein and lycopene. These are also the carotenoids most commonly found in foods (Rodriguez-Amaya,
1993, 1999).

The provitamin A activity of some carotenoids (e.g. $\beta$-carotene, $\alpha$-carotene, $\beta$-cryptoxanthin) has been known for a long time. In more recent years, carotenoids, provitamins A or not, have been credited with other health-promoting effects: immunoenhancement and reduction of the risk of developing degenerative diseases such as cancer, cardiovascular diseases (CVD), cataract and macular degeneration (Gaziano and Hennekens, 1993; Krinsky, 1993; Mayne, 1996; Olson, 1999; Krinsky and Johnson, 2005). These physiological activities have been attributed to an antioxidant property, specifically to the ability to quench singlet oxygen and interact with free radicals (Palozza and Krinsky, 1992; Palace et al., 1999). However, other mechanisms of action against chronic diseases have been increasingly cited: modulation of carcinogen metabolism, regulation of cell growth, inhibition of cell proliferation, enhancement of cell differentiation, stimulation of cell-to-cell gap junctional communication, retinoid-dependent signalling and filtering of blue light (Astorg, 1997; Olson ,1999; Stahl et al., 2002; Krinsky and Johnson, 2005; Stahl and Sies, 2005).

In the 1980s, numerous retrospective and prospective epidemiological studies in various countries consistently and strongly showed that dietary intake of $\beta$-carotene or its serum level was inversely associated with the incidence of cancer, particularly lung cancer (Ziegler, 1991; Block et al., 1992; Ziegler et al., 1996). This inverse relation was also seen with CVD (Gaziano and Hennekens, 1993; Kohlmeier and Hasting, 1995; Mayne, 1996). $\beta$-carotene, however, fell into disrepute when intervention studies gave the unexpected finding that this carotenoid given in capsules to smokers and asbestos workers increased rather than reduced the incidence of lung cancer (ATBC Study Group, 1994; Omenn et al., 1996).

It was later recognized that $\beta$-carotene was administered alone in the intervention studies at doses (20-30 mg) much higher than the optimum daily intake in the epidemiological studies (about 4 $\mathrm{mg}$ ), in which the diets had other carotenoids and other food constituents that could act jointly with $\beta$ carotene (CARIG, 1996). Moreover, the participants in the intervention trials were heavy smokers or 
workers exposed to asbestos for a long time; the oxidative or cancer process might have reached a stage at which the carotenoid could no longer be effective. With these considerations, carotenoids regained their prominence but the current emphasis is on carotenoids other than $\beta$-carotene.

Lycopene's possible role in the prevention of cancer has drawn considerable attention (Gerster, 1997; Clinton, 1998; Sies and Stahl, 1998; Giovannucci, 1999; Rao \& Agarwal, 1999; Rissanen et al., 2002), with special emphasis on prostate cancer (Giovannucci et al., 2002; Hadley et al., 2002; Wertz et al., 2004; StacewiczSapuntzakis and Bowen, 2005). This carotenoid has also been associated with CVD prevention (Kohlmeier and Hastings, 1995). A case-control study of 1379 men from 10 European countries (EURAMIC Study) showed that higher lycopene concentration in body fat was correlated with a lower risk of heart attack (Kohlmeier et al., 1997a).

Lutein and zeaxanthin make up the yellow pigment in the macula of the human retina (Bone et al., 1988; Handelman et al., 1988) and have been associated with the reduced risk for macular degeneration (EDCC, 1993; Seddon et al., 1994), the principal cause of irreversible blindness in the elderly. These two carotenoids have also been consistently linked to the lowering of the risk for cataract (Moeller et al., 2000).

Although numerous studies support the protective effect of carotenoids against chronic diseases, there have been some inconsistencies in the results, requiring more well-designed studies to be conducted. The consumption of carotenoid-rich foods is widely recommended, but caution and more investigations are recommended to evaluate the benefits and risks of supplementation (Mayne, 1996; Granado et al., 2003; Krinsky and Johnson, 2005).

\section{Phenolic compounds}

Phenolic compounds comprise one of the most numerous and widely distributed groups of substances in the plant kingdom, with more than 8000 phenolic structures currently known (Bravo, 1998). Natural phenolics can range from simple molecules, such as phenolic acids, to highly polymerized compounds, such as tannins, and their occurrence in foods is extremely variable.
The most common group of plant phenolics are the flavonoids, the structures of which are based on that of flavone, consisting of two benzene rings linked through a three-carbon $\gamma$-pyrone ring. Common classes of flavonoids include flavones, flavonols, isoflavones, anthocyanins, catechins (flavanols) and flavanones. More than 4000 flavonoids have been reported and, except for catechins (Aherne and O'Brien, 2002), most flavonoids occur in nature as glycosides.

Flavonoids are found in fruits, vegetables, coffee, tea and wine. The flavonols quercetin, kaempferol and myricetin are widely distributed in fruits and vegetables. Berries, tomato, potato, broad beans, broccoli, Italian squash, apple, kale and onion are the richest sources of quercetin (Hertog et al., 1993; Hollman and Artz, 2000; Aherne and O'Brien, 2002). Radish, horseradish, endive and kale are relatively high in kaempferol (Hertog et al., 1993). Naringenin (a flavanone), rutin (a flavonol glycoside) and tangeretin (a methylated flavone) are found in citrus fruits.

The health-related properties of phenolic compounds, particularly flavonoids, are believed to be based on their antioxidant activity as hydrogen donating free radical scavengers (Rice-Evans et al., 1996; Prior and Cao, 2000). The primary target of radicals are proteins (including enzymes), lipids (relevant to the induction of heart disease), DNA (relevant to the induction of cancer) and RNA. However, the oxidative event that occurs most frequently inside the body is the oxidation of the unsaturated fatty acid components of cell membranes forming lipid peroxides. Many researchers have shown that lipid peroxides and reactive oxygen species are involved in the development of a variety of diseases, including cancer, atherosclerosis, heart disease, kidney damage, and even accelerated aging (Ames et al., 1993; Yu, 1996). Flavonoids are also metal chelators and have been found to bind metals, such as copper and iron, that catalyze lipid oxidation.

Yang et al. (2001) reviewed the inhibition of carcinogenesis by dietary polyphenolic compounds and questioned the link between the antioxidative and anticarcinogenic properties, asserting that polyphenols may inhibit carcinogenesis by affecting the molecular events in the initiation, promotion and progression stages of cancer. Beyond their antioxidative properties, flavonoids may act in a variety of ways, such as deactivating carcinogens, inhibiting the expression 
of mutated genes and the activity of enzymes that promote carcinogenesis, promoting detoxification of xenobiotics (Kris-Etherton et al., 2002).

Although flavonoids are widely distributed in plant foods, the isoflavones are found in just a few botanical families. Although present in several legumes, soybean is the principal dietary source. The isoflavones genistein and daidzein and their $\beta$ glucosides are present at up to $3 \mathrm{mg}$ per $\mathrm{g}$ of soybean (Price and Fenwick, 1985).

Isoflavones, lignans and stilbenes are phytoestrogens, a group of nonsteroid plant constituents that elicit estrogen-like biological response (Murphy and Hendrich, 2002). Lignans are diphenols associated as minor components with dietary fiber. Dietary sources of lignans are oilseeds, cereal grains, vegetables, fruits and legumes. Flaxseed and sesame seed have been identified as the richest sources of these compounds (Thompson et al., 1991; Coulman et al., 2005). Once ingested, plant lignans are converted by bacteria in the large intestine into enterolactone and enterodiol, which are called mammalian lignans because they have been found only in mammals (Crosby, 2005). Mammalian lignans are associated with a reduced risk of CVD and cancer.

Stilbenes are 1,2-diaryl ethenes that are biosynthesized from cinnamic acid derivatives. They are widely distributed in liverworts and higher plants in monomeric, dimeric, trimeric and polymeric (viniferins) forms (Gorham, 1989). Among monomeric stilbenes, the major active compound is trans-resveratrol, and most of the physiological studies have focused on it (Cassidy et al., 2000). The main dietary sources of stilbenes are grape and peanut, and their products. Trans-resveratrol is a phytoallexin that protects grape vines from fungal infection.

Phytoestrogens can compete with steroid hormones for various enzymes and receptors and stimulate production of sex hormone-binding globulin in the liver. Thus, they may alter steroid hormone metabolism and may inhibit growth and proliferation of hormone-dependent cancer. Like other phenolic compounds, phytoestrogens have antioxidant activity, and like estrogens, they can influence lipoprotein metabolism and enhance vascular reactivity. Phytoestrogens, therefore, have potential protective effects against CVD.

Phenolic acids such as caffeic, ferulic and ellagic acids are widely distributed in fruits, vegetables, tea and wine; many are present in foods as glycosides. Ellagic acid is found in high concentrations in fruits and nuts, specifically raspberry, strawberry, blackberry, pecan and walnut (Hollman and Venema, 1993).

\section{Phytosterols and phytostanols}

Plant sterols or phytosterols are structurally similar and functionally analogous to the animal sterol, cholesterol. Phytosterols are triterpenoids occurring in both free and esterified form. Of more than 40 phytosterols identified, $\beta$-sitosterol, stigmasterol and campesterol are the most abundant and are predominantly supplied by vegetable oils (Piironen et al., 2000; Hicks and Moreau, 2001), which are rich sources of sterol esters. Ferulic acid esters of phytosterols, commonly known as oryzanol, occur in rice bran oil (Kaneko and Tsuchiya, 1954). Cereals, nuts and vegetables are also sources of sterols albeit of lesser importance.

A less abundant class of related compounds are the plant stanols or phytostanols, which are completely saturated forms of phytosterols. Phytostanols are derived primarily from corn, wheat, rye and rice (Hicks and Moreau, 2001). Corn fiber oil, said to be a unique oil, not only contains fatty acid and phenolic esters of phytosterols, but also appears to be the richest source of stanols and stanol esters (Moreau et al., 1996).

Phytosterols and phytostanols inhibit intestinal absorption of cholesterol. The cholesterol-lowering property of these compounds has been established some decades ago. For instance, $\beta$-sitosterol has been used since the 1950s as a supplement and as a drug (Cytellin, marketed by Eli Lilly) for lowering serum cholesterol levels in hypercholesterolemic individuals (Hicks and Moreau, 2001).

Equally effective in lowering plasma cholesterol, plant sterol esters, unlike stanols, increase their own absorption. The resulting increased serum sterol levels could occasionally approach values seen in phytosterolemia, a strongly atherogenic hereditary metabolic abnormality. Thus, plants rich in esterified 
stanols would be preferable in the preparation of functional foods (Miettinen, 2001).

As of September 2000, the US FDA has allowed a health claim for reducing the risk of coronary heart disease for foods (spreads and salad dressings) containing phytosterol and phytostanol esters (Jones and Raeini-Sarjaz, 2001).

\section{Tocotrienols}

Tocotrienols are unsaturated analogs of tocopherol (vitamin E). They occur in the unsaponifiable fraction of vegetable oils; rice bran oil and palm oil are the most significant sources (Eitenmiller, 1997). A number of plant foods, ranging from kale and broccoli, to cereal grains and nuts have also been found to contain tocotrienols (Piironen et al., 1986).

There are at least four known forms of tocotrienol, with $\gamma$-tocotrienol as the main and most potent cholesterol-lowering form (Parker et al., 1993). The cholesterol-lowering effect of tocotrienols is attributed to their ability to inhibit hydroxymethylglutaryl-CoA (HMG-CoA) reductase, the rate-limiting enzyme in the cholesterol synthesis pathway (Parker et al., 1993). It has been suggested that $\alpha$-tocopherol attenuates the inhibitory effect of $\gamma$-tocotrienol (Qureshi et al., 1996). Tocotrienols have also been demonstrated to possess vitamin $\mathrm{E}$ activity (Tan, 1989), antioxidant activity (Serbinova et al., 1993) and antitumor properties (Komiyama et al., 1992). It was hypothesized that the inhibition of HMG-CoA reductase by tocotrienols also results in suppression of tumor growth (Elson and Qureshi, 1995).

\section{Organosulfur compounds}

Allium compounds are organosulfur compounds (OSCs) found in Allium vegetables such as garlic, onion, scallion, chive, shallot and leek, which account for the distinctive flavor and aroma as well as the many reported medicinal effects of these vegetables.

The OSCs in Allium vegetables have been reported to exert various physiological effects, including antimicrobial activity, lipid-lowering effect, hypocholesteremic activity, antithrombic effect, inhibition of platelet aggregation, hypoglycemic activity, and lipoxygenase and tumor inhibition (Huang et al., 1994).

The glucosinolates are sulfur-containing glucosides prevalent in the cruciferous family of vegetables, especially the Brassicas (e.g. cabbage, broccoli, Brussels sprouts, cauliflower), and are also present at relatively high levels in oilseeds such as rapeseed and in condiments such as mustard seed. Over a hundred different glucosinolates have been identified in the plant kingdom, but only about 10 are present in cruciferous vegetables (Stoewsand, 1995). Although the glucosinolates are structurally diverse, there are only three principal groups, based on the side-chain structure: aliphatic, aromatic and indolyl (heteroaromatic) glucosinolates (Mithen et al., 2000). All the glucosinolates have a $\beta$-D-thioglucose group, a sulphonated oxime moiety and a variable side-chain derived from methionine, tryptophan, phenylalanine or some branched-chain amino acids (Fenwick et al., 1983).

When the plant tissue is damaged by food preparation or chewing, the glucosinolates are brought into contact with and are hydrolyzed by the endogenous enzyme, myrosinase, to yield a complex mixture of products mainly isothiocyanates, nitriles and thiocyanates. Glucosinolate breakdown products exert a variety of antinutritional and toxic effects in higher animals, the most thoroughly studied of which is the goitrogenic effect of some products (Heaney \& Fenwick, 1995). At present there is little or no epidemiological evidence of this goitrogenic effect causing a disease in humans.

On the other hand, as summarized by Finley (2005), in vitro and in vivo studies have reported that isothiocyanates affect many steps of cancer development, including modulation of phase I and II detoxifying enzymes, functioning as a direct or indirect antioxidant by phase II enzyme induction, modulating cell signaling, induction of apoptosis (programmed cell death), control of the cell cycle and reduction of Helicobacter infections. Apoptosis and modulation of phase I and phase II detoxification pathways have been considered the most important mechanisms by which glucosinolate/isothiocyanates inhibit carcinogenesis (Mithen et al., 2000; Talalay \& Fahey, 2001; Finley, 2005). Glucosinolates are not bioactive until they have been enzymatically hydrolyzed to the associated isothiocyanates. 


\section{Nondigestible carbohydrates: Dietary fiber and prebiotics}

There are 3 main types of carbohydrates that are undigestible in the human small intestines: nonstarch polyssacharides (NSP), resistant starch (RS) and nondigestible oligosaccharides (NDOs) (Voragen, 1998).

Several definitions for dietary fibers have been suggested. The most widely accepted is a physiological definition, which considers dietary fibers as vegetable wall residues that are resistant to enzymatic hydrolysis in the small intestine. A chemical definition describes dietary fibers as nonstarch polysaccharides, although more recently some workers include resistant starch as a new class. The most commonly used definition is: dietary fibers are oligosaccharides, polysaccharides and their hydrophilic derivatives, which cannot be digested by the human digestive enzymes to absorbable components in the upper alimentary tract; this definition includes lignin (Thebaudin et al., 1997).

NDOs occur naturally in food raw materials and food products. The most prominent example are fructans (e.g. inulin), which occur in edible parts of various plant foods like onion, artichoke, chicory, leek, garlic, banana, rye, barley and yacon (Voragen, 1998). Galactosyl sucroses (raffinose and stachyose) are found in soybeans and other leguminous seeds, while xylooligosaccharides occur in bamboo shoots. In some foods NDOs are generated during processing. The NDOs have been described as prebiotics (Crittenden and Playne, 1996). A prebiotic is a nondigestible food ingredient that positively affects the host by selectively stimulating the growth and/or activity of one or a limited number of beneficial bacterial species already resident in the colon (Gibson and Roberfroid, 1995). For this reason, resistant starches, although considered as fibers, are not necessarily prebiotics.

Dietary fibers have several recognized physiological effects: modulation of glucose absorption, regulation of gastrointestinal transit time, fecal bulking, acidification of colonic content and control of cholesterol bioavailability. Prebiotics on the other hand, selectively modify the colonic microbiota and modulate hepatic lipogenesis (Crittenden and Playne, 1996; Roberfroid, 1996).
A balanced intestinal flora allows improved bowel regularity, reduction of bacteria, protection against a wide range of toxins and increased nutrient absorption.

\section{Functional Foods from Plant Sources}

While the evidence for individual phytochemicals is not as compelling, overwhelming evidence from epidemiological studies, biological and experimental studies, and clinical intervention trials has demonstrated that a plant-based diet can reduce the risk of degenerative diseases, especially cancer and CVD (Block et al., 1992; Ames et al., 1993; Steinmetz and Potter, 1996; Ness and Powles, 1997; World Cancer Research Fund, 1997; Law and Morris, 1998; Kaur and Kapoor, 2001). It is estimated that plant-based diets prevent $20-50 \%$ of all cases of cancer (Steinmetz and Potter, 1996; World Cancer Research Fund, 1997). Thus, dietary recommendations for the prevention of cancer and other chronic diseases have always emphasized the consumption of a variety of plant foods. The single compound approach has given way to the concept that overall protection against disease is provided by a range of phytochemicals contained in foods.

Following are plant foods that are established or emerging functional foods, each one with a body of scientific evidence on the positive impact on health that the constituent nutrients and phytochemicals confer.

\section{Broccoli and other cruciferous vegetables}

Cruciferous vegetables contain little fat, are low in energy, and are sources of micronutrients (vitamins A, C and E, folic acid, selenium), fiber and other phytochemicals (carotenoids, coumarins, flavonoids and other phenolic compounds, and glucosinolates) (Steinmetz and Potter, 1996; Delaquis and Mazza, 1998).

A review of 87 case-control studies (Verhoeven et al., 1996) revealed an inverse association between consumption of cruciferous vegetables and cancer risk. This epidemiological evidence is supported by a host of experimental studies, which have indicated that glucosinolate breakdown products exert anticarcinogenic activity in experimental and animal models (Verhoeven et al., 1997; Hecht, 1999). 
Stoewsand (1995) specifically attributed the cancer chemopreventive effects of Brassica vegetables to two types of phytochemicals: certain glucosinolates and $S$-methyl cysteine sulfoxide.

The indolyl glucosinolate, glucobracissin, found in high levels especially in Brussels sprouts, is hydrolyzed by myrosinase to give indole-3carbinol (I3C). This indole is under investigation for its chemopreventive property, especially toward the mammary gland. It may reduce cancer risk by increasing 2-hydroxylation over 16-hydroxylation of estrogen - this shift in hydroxylation represents a reduction in estrogenic activity and may be protective against estrogen-related cancers (Hasler, 1998).

In a human clinical trial, women were given a massive daily dose of $500 \mathrm{mg}$ I3C (approximately 50 times the estimated average daily intake in the USA) for one week, resulting in significantly increased 2hydroxylation of estradiol (Michnovicz and Bradlow, 1991). The result suggested that I3C may be a novel approach for reducing the risk of breast cancer. However, animal studies have shown that I3C and other indoles induce both phase I and II enzymes. Induction of phase I enzymes could activate or deactivate carcinogens, while induction of phase II enzymes leads to detoxification. Thus, caution has been urged before proceeding to extensive clinical trials (Dashwood, 1998), although similar phase I clinical trials as the one described above, are ongoing (Wong et al., 1998).

Three-day-old sprouts of cultivars of certain crucifers, including broccoli and cauliflower, contain 10-100 times higher levels of the aliphatic glucosinolate glucoraphanin than the corresponding mature plants (Fahey et al., 1997). Glucoraphanin is hydrolyzed by myrosinase to yield sulforaphane, an isothiocyanate, which is a phase II enzyme inducer (Zhang et al., 1992). Hence, broccoli sprouts have more desirable anticancer properties than the mature vegetable (Fahey et al., 1997; Nestle, 1998).

\section{Oat}

Among the food grains, oat is the most concentrated source of $\beta$-glucan, a soluble nonstarch polysaccharide known to reduce risk of coronary heart disease (Bell et al., 1999). Various components such as phytates, phenolics, vitamins and minerals, which confer other physiological benefits, are also present.

Oat was the first specific food allowed to have a health claim under the US Nutrition Labeling and Education Act (Hasler, 1998). FDA allowed the claim "soluble fiber from oatmeal, as part of a low saturated fat, low cholesterol diet, may reduce the risk of heart disease." FDA has acknowledged that $\beta$-glucan is the main active ingredient responsible for this health claim (Oomah and Mazza, 1999).

Several clinical studies starting from 1963 (DeGroot et al., 1963) were conducted to see the effect of oats on serum lipids. The most conclusive study was a meta-analysis (Ripsin et al., 1992) summarizing the oat-product literature on clinical trials of freeliving subjects up to March 1991. Twenty trials were identified, out of which 12 trials became the bases of analyses. This report provided the strongest evidence to FDA that about $3 \mathrm{~g}$ per day of soluble fiber from oat products can achieve a clinically relevant serum cholesterol-lowering effect, and that the reduction is greater in individuals with higher initial blood cholesterol levels.

Four mechanisms have been proposed to explain the cholesterol-lowering effect of $\beta$-glucan from oats (Bell et al., 1999). First, it has been postulated that soluble fiber binds to bile acids in the intestinal lumen resulting in a reduced bile acid pool circulating back to the liver. This binding action stimulates the production of more bile acids from cholesterol, thereby reducing serum cholesterol concentration (Lia et al., 1997). A second mechanism centers on the short-chain fatty acids (acetic, propionic and butyric acids) that are formed from fermentation of soluble fibers in the large bowel by colonic bacteria (Glore et al., 1994). These fatty acids are absorbed through the portal vein, inhibiting the action of $\mathrm{HMG}-\mathrm{CoA}$ reductase or increasing catabolism of LDL cholesterol. A third mechanism involves the delaying of gastric emptying by oat soluble fiber - this reduces post-prandial serum insulin concentrations (Inks and Mathews, 1997), which in turn reduces hepatic cholesterol production through mediation of HMG-CoA reductase. Lastly, the increase in intestinal viscosity brought about by oat soluble fiber may interfere with the absorption of dietary fat, including cholesterol (Inks and Mathews, 1997). 


\section{Flaxseed (linseed)}

Flaxseed or linseed is a rich source of the omega 3-fatty acid $\alpha$-linoleic acid (ALA), viscous fiber components and mammalian lignan precursors (Oomah and Mazza, 1999). The high concentrations of dietary fiber (polysaccharide gum or mucilage), ALA and lignans have been associated with the many potential health benefits of flaxseed.

The first meta-analysis examining the relationship between intake of flaxseed or its components and risk reduction of disease in humans was presented by Oomah (2001). Of 24 clinical studies identified, only 12 (six with flaxseed and six with flaxseed oil), involving a total of 208 subjects, were found to meet all the criteria of well-designed clinical trials. Four of these studies supported the protective effect of ALA of flaxseed oil against cardiovascular disease. Three studies concluded that consumption of raw or defatted flaxseed reduced total and LDL cholesterol. Five studies in women showed a role of flaxseed in mediating bone health and its phytoestrogenic and therapeutic effect in reducing the risk of hormonerelated cancers.

\section{Tomato}

Tomato and tomato products have been the focus of intense investigation in recent years, especially in relation to prostate cancer (Giovannucci et al., 2002; Hadley et al., 2002; Campbell et al., 2004; Stacewicz-Sapuntzakis \& Bowen, 2005). Giovannucci (1999) reviewed the epidemiological literature on the relationship between intake of tomatoes and tomatobased products and plasma levels of lycopene and risks of various cancers. Among 72 studies identified, 57 reported inverse associations between tomato intake or blood lycopene level and the risk of cancer at defined anatomical sites, and 35 of these inverse associations were statistically significant. No study indicated that higher tomato consumption or blood lycopene level increased the risk of cancer at any of the sites investigated. Evidence for a benefit was strongest for cancers of the lung, stomach and prostrate gland. Data were also suggestive of a benefit for cancers of the pancreas, colon and rectum, esophagus, oral cavity, breast and cervix.

Tomatoes and tomato-based products are the major sources of lycopene in the diet of many countries and lycopene has been considered the primary phytochemical responsible for the reduction in the risk of prostate cancer. Tomato, however, is also a rich source of nutrients such as folate and vitamins $\mathrm{C}$ and $\mathrm{E}$, and of other potentially beneficial phytochemicals including phenolic acids, phytosterols and flavonoids (Beecher, 1998). Thus, the possibility that it is the combination of these compounds that is responsible for the influence on prostrate carcinogenesis has been raised (Hadley et al., 2002; Campbell et al., 2004; Stacewicz-Sapuntzakis \& Bowen, 2005).

\section{Soybean}

Soybean has been cultivated and consumed as food in Asia for over 5000 years. But this ancient bean was grown abundantly throughout the world only during the $20^{\text {th }}$ century and scientific interest on its health benefits started even much later. Soybean is not only a source of high quality proteins but also of phytosterols, saponins, phenolic acids, phytic acid and isoflavones (Messina and Barnes, 1991).

Soybean has been known to have a protective role in women's health, particularly the alleviation of menopausal symptoms and promotion of bone health. A clinical study of 66 postmenopausal women found that daily intake of $40 \mathrm{~g}$ isolated soy protein (ISP), containing $90 \mathrm{mg}$ total isoflavones, significantly increased (approximately 2\%) both bone mineral content and density in the lumbar spine after 6 months (Erdman and Potter, 1997). This finding suggests that soybeans may have a protective role in osteoporosis. Asian women have significantly lower levels of hot flashes and night sweats compared to western women. A clinical study showed that daily intake of $60 \mathrm{~g}$ ISP for 3 months reduced hot flashes by $45 \%$ in 104 postmenopausal women (Albertazzi et al., 1998). Considering the significant placebo effect in these studies, however, use of soybean as substitute for hormone replacement therapy was considered premature (Hasler, 1998).

Human ecological observations support a cancer-protective effect of soybeans. Vegetarians and population groups (e.g. Japanese women) who often consume relatively greater amounts of soy products, have a lower risk of certain cancers, including breast cancer (World Cancer Research Fund, 1997). Several classes of anticarcinogenic phytochemicals have 
been identified in soybeans, of which the isoflavones genistein and daidzein are noteworthy because soybeans are the only significant dietary sources of these compounds. At present, the epidemiological data on soy intake and cancer risk are not consistent (Kris-Etherton et al., 2002). However, a number of experimental studies have indicated a protective role of soybeans and its components in cancer.

Population studies show that countries consuming diets high in soy products have the lowest rates of CVD. An inverse association between soy food product consumption and cholesterol level has been observed in Japanese men and women (Nagata et al., 1998). A meta-analysis (Anderson et al., 1995) of 38 controlled clinical trials with a total of 730 subjects showed that daily consumption of $47 \mathrm{~g}$ soy protein resulted in significant decreases in total cholesterol (9\%), LDL cholesterol (13\%), and triglycerides (11\%) and an increase in HDL cholesterol (2\%).

The most well-documented physiological effect of soybean is its cholesterol-lowering effect. Investigations on the specific components responsible for this effect of soybean have focused on the isoflavones. In two studies, however, isoflavone supplements were found not effective in lowering cholesterol in humans (Nestel et al., 1997; Hodgson et al., 1998). On the other hand, Crouse and co-workers (1999) showed that naturally occurring isoflavones $(62 \mathrm{mg})$ isolated with soy protein reduced the plasma concentrations of total and LDL cholesterol, without affecting concentrations of triacilglycerols or HDL cholesterol, in mildly hypercholesterolemic individuals. Ethanol-extracted soy protein (with only $3 \mathrm{mg}$ isoflavones) was ineffective.

Animal studies indicate that the cardioprotective effect of soybeans goes beyond cholesterol-lowering (Potter, 1998), such as decreases of atherosclerotic lesion and thrombus formation and in atherosclerotic plaque. In 1999, the Food and Drug Administration of the U.S. approved a health claim for soy protein in reducing the risk of heart disease (Department of Health and Human Services, 1999).

\section{Citrus}

Citrus fruits are principal sources of vitamin C, folate, fiber, flavonoids and phenolic acids, monoterpenes, carotenoids and limonoids (Girard and
Mazza, 1998). The various health benefits of citrus fruits have been attributed to the antioxidant activity of their constituent flavonoids (flavanones, flavones, flavonols and anthocyanins) (Benavente-Garcia et al., 1997). In biological studies, citrus flavonoids demonstrated anticarcinogenic (antimutagenic and antiproliferative effects, inhibition of carcinogenic cell invasion) and cardiovascular (effects on capillary fragility, platelet aggregation, coronary heart disease) properties. Citrus flavonoids have also been found to have antiinflammatory, antiallergic, and antiviral activities.

The monoterpene D-limonene, which is the major component of the oil from citrus peel, has also been shown to protect against cancer; it induces glutathione transferases, a family of phase II detoxification enzymes (Crowell, 1997; Gould, 1997). A GRAS (generally regarded as safe) status has been given to $\mathrm{D}$-limonene as a flavoring agent. Having no toxicity in humans, D-limonene is a good candidate for human clinical chemoprevention trial evaluation. Perillyl alcohol, a metabolite of limonene, has undergone phase I clinical trials in patients with advanced malignancies (Ripple et al., 1998).

Citrus fruits are particularly rich in another class of phytochemicals, the highly oxidized triterpenes called limonoids. Recent research suggests that these compounds may have substantial anticancer activity. However, these studies have been conducted primarily in in vitro and animal models, requiring further human studies to confirm such action (Ejaz et al., 2006)

\section{Berries}

Berries are not only delicious, low energy food, but also rich sources of fiber, antioxidant vitamins and various phenolic compounds (flavonoids and phenolic acids). The main classes of flavonoids in berries are anthocyanins, proanthocyanidins, flavonols and catechins (Wang et al., 1997). Phenolic acids present in berries are hydroxylated derivatives of benzoic acid and cinnamic acid (Wang et al., 1997; Torronen, 2000). Various potential health benefits from berries have been attributed to flavonoids and phenolic acids.

Berries of Vaccinium sp. have been reported to possess a wide range of biological activities. Cranberry and wild blueberry have been shown to prevent urinary tract infections. This protective effect has been 
attributed to condensed tannins or proanthocyanidins, which are said to act as anti-adhesive agents preventing bacterial colonization (Howell et al., 1998; Ofek et al., 1996). In wild blueberry, proanthocyanidins have also been identified as the active agents inhibiting the in vitro promotion of chemically-induced carcinogenesis (Bomser et al., 1996).

Fruit extract of wild bilberry inhibited LDL oxidation (Laplaud et al., 1997), exhibited astringent and antiseptic properties, decreased permeability and fragility of capillaries, inhibited platelet aggregation, inhibited urinary tract infection, and strengthened collagen matrices via cross linkages (Morazzoni and Bombardelli, 1996; Morazzoni and Magistretti, 1990).

\section{Tea}

Tea was first discovered in China, where it has been consumed for its medicinal properties since 3000 BC (Balentine, 1997). The three main types of tea are green (unfermented), oolong (semi-fermented) and black (fully fermented). Green tea contains significant amounts of catechins, which are easily extracted from the leaves into hot water infusions. During the manufacture of black tea, the dimeric theaflavins and thearubigens are formed by enzymecatalyzed oxidation of catechins. Green tea contains catechins $(90 \%)$ and flavonols $(10 \%)$; black tea has catechins $(30 \%)$, flavonols $(10 \%)$, theaflavins $(13 \%)$ and thearubigens (47\%) (Tijburg et al., 1997).

Tea has been shown to possess antiviral, antifungal and antibacterial properties. Evidence has also suggested that drinking tea provides protection against cancer and CVD, and it is generally believed that flavonoids are mainly responsible for these biological actions. An ecological study of residents of Shizuoka, Japan, where green tea is produced and consumed, revealed lower mortality rates from stomach, lung and liver cancers than comparable populations in non-green tea consuming areas (Oguni et al., 1992). Epidemiological studies have shown that tea may reduce the risk for certain cancers (Blot et al., 1996; Kohlmeier et al., 1997b). Overall, however, the epidemiological evidence for a protective effect of tea against cancer and CVD is still considered inconclusive (Tijburg et al., 1997; World Cancer Research Fund, 1997; Kris-Etherton et al., 2002). In contrast, research findings from animal and in vitro studies clearly support a cancer chemopreventive effect for tea, which spans the whole process of carcinogenesis (Dreosti, 1996; Kuroda and Hara, 1999; Wang et al., 2000). Similarly, the alleged protection against CVD had also rested heavily on cellular and animal experiments, carried out at conditions and/or concentrations unlikely to occur in man (Tijburg et al., 1997).

A study of green tea drinkers from Japan (Kono et al., 1992) and another in Norway (probably mainly black tea drinkers) (Stensvold et al., 1992) revealed a significant inverse relationship between tea drinking and plasma cholesterol levels. A similar but not statistically significant trend was observed in presumably black tea drinkers from Israel (Green and Harari, 1992). Additional evidence for a protective effect of tea against CVD - lowering of blood pressure and a trend towards reduced coronary heart disease mortality - was found in the Norwegian study. These protective effects were also observed in a study of a population of elderly men in the Netherlands, although the association was seen with above average consumption of dietary flavonoids (quercetin, kaempferol, myricetin, apigenin and luteolin), which were largely derived from tea (Hertog et al., 1993).

\section{Grapes and wine}

Grapes and wines contain large amounts of phenolic compounds including flavonoids (catechins, epicatechin, quercetin, anthocyanidins), phenolic acids (hydroxycinnamates) and tannins (Kaur and Kapoor, 2001). The phenolic substances in wine mainly originate from grapes, but the phenolic profile of wine is not the same as that of fresh grapes or grape juice due to significant changes taking place during wine making.

In certain parts of France, coronary heart disease mortality is low despite diets high in dairy fat (Renaud and de Lorgeril, 1992). This phenomenon, referred to as the 'French Paradox' is attributed to high intake of red wine and has been partly explained by the association of moderate alcohol consumption with a decreased risk of CVD. More recent investigations have focused on the nonalcoholic components, particularly flavonoids and other phenolics; the phenolic content of red wine is 20-50 times that of white wine. Red wine has been shown to inhibit oxidation of human LDL in vitro (Frankel et al., 1993; Teissedre et al., 1996), this property being attributed to 
wine phenolics. Collectively, as reviewed by Rotondo and Gaetano (2000) and Wollin and Jones (2001), phenolic compounds appear to have anti-thrombic effects as a result of reduced susceptibility of platelet aggregation, reduced synthesis of prothrombotic and proinflammatory mediates, decreased expression of adhesion molecules and tissue factor activity. The inhibition of platelet-mediated thrombosis was also observed with grape juice (Freedman et al., 2001).

Aside from its antioxidant activity, resveratrol, found in grape skin and red wines, induces quinone reductase, a phase II detoxifying enzyme. It has antiinflammatory activity and inhibits the hydroperoxidase activity of cyclooxygenase, thereby inhibiting the arachidonic pathway that produces prostaglandins which stimulate tumor cell growth (Cassidy et al., 2000). In a dose-dependent manner, resveratrol inhibits the development of preneoplastic lesions, slowing down the progression of carcinogenesis (Jang et al., 1997). Other reports suggest that resveratrol inhibits key enzymes involved in DNA duplication and synthesis (Fontecave et al., 1998; Sun et al., 1998). As pointed out by della Ragione and co-workers (1998), resveratrol seems a very attractive molecule for the development of anticancer treatments as well as for inhibiting lymphocyte proliferation during immunosuppressive therapies.

\section{Garlic}

Garlic is one of the earliest of cultivated spices and foods and the most widely quoted in the literature for medicinal properties and health benefits. A number of epidemiological studies have shown that garlic consumption is correlated to reduced cancer risk. An ecological study showed that Shandong Province, China, an area where garlic consumption is very high, had the lowest national mortality rate for stomach cancer (Mei et al., 1982). You et al. (1989) found that eating more than $1.5 \mathrm{~kg}$ /year of garlic was accompanied by a significantly lower stomach cancer risk. The Iowa Women's Health Study showed a reduced colon cancer risk by almost $50 \%$ in over 40000 women who consumed garlic more than once a week (Steinmeitz et al., 1994). A review of 20 epidemiological studies by Ernst (1997) suggested that allium vegetables, including garlic, may confer a protective effect against cancer of the gastrointestinal tract. In a more recent meta-analysis, a consistent inverse association between raw and cooked garlic consumption and stomach and colorectal cancers was observed (Fleischauer et al., 2000). In contrast, garlic supplement consumption in one case-control study of prostate cancer and in four studies from the Netherlands, cohort of colorectal, stomach, lung and breast cancers, did not appear to be associated with cancer risk.

Components of garlic have been demonstrated to inhibit carcinogenesis in several experimental models. These studies have suggested that allyl sulfur compounds in garlic act primarily on the initiation phase of carcinogenesis, inhibiting development of chemically-induced tumors in various sites through the induction of phase II detoxification enzymes and inhibition of P $450 \mathrm{E} 1$, the enzyme responsible for the metabolic activation of carcinogens. The ability of garlic to inhibit the synthesis of $N$-nitroso compounds (Mei et al., 1989) and its antibacterial activity against Helicobacterpylori, a risk factor in stomach cancer (Sivam et al., 1997), are two other possible mechanisms. Studies have indicated that the anticancer properties associated with garlic are not limited to a particular tissue and both lipid-soluble and water-soluble allyl sulfur compounds are effective, supporting the possibility of multiple mechanisms (Milner, 2006).

Evidence from many experimental studies shows that garlic protects against CVD by bringing about lipid normalization, enhanced fibrinolytic activity, inhibited platelet aggregation and reduced blood pressure (Petesch and Sumiyoshi, 1999). These experimental studies are supported by ecological observations of lowered cardiovascular incidence in high-garlic consuming populations in the Mediterrenean region and some places in Asia, compared to populations who have similar life and dietary styles (Lin, 1994). Several clinical trials have been conducted to investigate the cardioprotective effect of garlic. A clinical study on the effect of garlic supplementation on the endpoint of cardiovascular events (myocardial infarction or death) was conducted in 432 cardiac patients (Bordia and Verma, 1990). Supplementation reduced the mortality rate by $50 \%$ in the second year and by about $66 \%$ in the third year, and reduced the rate of re-infarction by 30 and $60 \%$ in the second and third year, respectively. A meta-analysis by Warshafsky and co-workers (1993) summarized the results of 5 randomized placebo-controlled clinical trials involving 410 patients. It was shown that an 
average of $900 \mathrm{mg}$ garlic per day (one-half to one clove of garlic) could decrease total serum cholesterol levels by approximately $9 \%$. Another meta-analysis involving 16 trials reported that $800 \mathrm{mg}$ garlic per day reduced total cholesterol by 12\% (Silagy and Neil, 1994). On the other hand, a multi-center, randomized, placebo-controlled trial showed that 12 weeks of garlic intake were ineffective in lowering cholesterol levels in hypercholesterolemic subjects (Isaacsohn et al., 1998). The contradictory results in these studies may be due to methodological shortcomings, differences in garlic preparation/ formulation used (i.e., loss of active compounds during processing or inhibition of release of the active components) and insufficient duration of studies. Rahman and Lowe (2006) analyzed in vitro and in vivo studies published since 1993, concluding that although garlic appears to hold promise in reducing parameters associated with cardiovascular disease, more in-depth and appropriate studies are required.

\section{Prospect for Developing Countries}

In order to materialize the full potential of phytochemicals/functional foods, a holistic, concerted, multidisciplinary approach is imperative, involving workers in diverse fields such as nutrition, medical sciences, epidemiology, statistics, immunology, analytical and organic chemistry, biology, biochemistry, agriculture, food science, food technology and engineering.

The future of functional foods depends on the unequivocal demonstration of their efficacy in promoting health. Epidemiological and intervention studies, however, require large investigating teams of researchers from different areas, infrastructure to cope with large numbers of subjects and substantial financing to support the different activities for an extended period. Animal model and cell/tissue studies are more amenable to conditions in developing countries, but the results need to be validated in humans.

A practical approach for developing countries would be to keep abreast of advances in human health research in developed countries and concentrate efforts on the identification of local sources of phytochemicals for which the scientific evidence is strong. Accurate quantification of the phytochemicals, including monitoring and enhancing of their levels throughout the food chain, and product development for the domestic and international markets could then be accomplished.

Each country will have to identify and promote their own sources, as Canada (Oomah and Mazza, 1999), Japan (Namiki, 1994) and China (Dai and Luo, 1996) have already been doing. Many developing countries have a diversity of yet unstudied or understudied foods which can have higher levels of bioactive phytochemicals than those found in developed countries. The importance of databases on these compounds cannot be overemphasized. In fact, reliable data on food composition is a prerequisite to a successful epidemiological study so that reliable intakes could be calculated. And a country can forcefully promote its products only if their compositions are reliably known. In addition, exploitation of the beneficial effects of the phytochemicals depends on how fully we understand their behavior at the different stages of the food chain.

It is known that the phytochemical composition can vary markedly as a function of such factors as cultivar, degree of maturity at harvest, climatic or geographic effects, soil composition, cultivation practices, part of the plant utilized. Agronomic and post-harvest handling and processing measures can be taken to insure high levels of these compounds in the diet. Indeed, it is now increasingly recognized that optimization of the nutrient/phytochemical contents and profiles of foods, through conventional plant breeding and agronomic practices or genetic manipulation, is a viable strategy (Mithen et al., 2000; Parr and Bolwell, 2000; Schneeman, 2000; van den Berg et al., 2000; Miettinen, 2001). The possibility that manipulation of phytochemical metabolism by expensive molecular techniques may not substantially improve phytochemical contents beyond what can be achieved by traditional agricultural procedures (Parr and Bolwell, 2000) should not be overlooked.

Most of the phytochemicals are prone to degradation during processing and storage. Thus, food production must be coupled with optimum food processing and storage, which can profoundly affect the health-promoting potential of functional foods. In fact, as discussed earlier, processing is necessary to transform some phytochemicals into their active form. And as shown with carotenoids, food processing can increase bioavailability by facilitating the release of the bioactive compounds from the food matrix, 
the first step in the human digestive process (Gartner et al., 1997; Rock et al., 1998). Thus, processing conditions should be such that appreciable losses of the phytochemical are prevented while their bioavailability is enhanced.

\section{Acknowledgment}

To $\mathrm{CNPq}$ for the visiting research fellowship granted to the first author and to CNPq and FAPESP for the financial support of our work in this area through the PRONEX projects nos. 66.2307/19968 and 2003/10151-4.

\section{References Cited}

Aherne SA, O'Brien NM. Dietary flavonols: Chemistry, food content and metabolism. Nutr. 2002; 18:75-81.

Albertazzi P, Pansini F, Bonaccorsi G, Zanotti L, Forini E, de Aloysio D. The effect of dietary soy supplementation on hot flushes. Obstet Gynecol. 1998; 91:6-11.

Ames BN, Shigenga M, Hagen TM. Oxidants, antioxidants and degenerative diseases of aging. Proc Natl Acad Sci USA. 1993; 90:7915-22.

Anderson JW, Johnstone BM, Cook-Newell ME. Meta-analysis of the effects of soy protein intake on serum lipids. New Engl J Med. 1995; 333:276-82.

Astorg P. Food carotenoids and cancer prevention: An overview of current research. Trends Food Sci Technol. 1997; 8:406-13.

ATBC (Alpha-Tocopherol, Beta-carotene) Cancer Prevention Study Group. The effect of vitamin E and beta-carotene on the incidence of lung cancer and other cancers in smokers. New Engl J Med. 1994; 330:1029-35.

Balentine D. Tea and health. Crit Rev Food Sci Nutr. 1997; 37:691-2.

Beecher GR. Nutrient content of tomatoes and tomato products. Proc Soc Exp Biol Med. 1998; 218: 98-100.

Bell S, Goldman VM, Bistrian BR, Arnold AH, Ostoff $G$, Forse RA. Effect of $\beta$-glucan from oats and yeast on serum lipids. Crit Rev Food Sci Nutr.
1999; 39:189-202.

Benavente-Garcia O, Castillo J, Marin FR, Ortuño A, del Rio JA. Uses and properties of Citrus flavonoids. J Agric Food Chem. 1997; 45:4505-15.

Block G, Patterson B, Subar A. Fruit, vegetables, and cancer prevention: A review of the epidemiological evidence. Nutr Cancer. 1992; 18:1-29.

Blot WJ, Chow WH, Maclaughlin JK. Tea and cancer: A review of the epidemiological evidence. Eur J Cancer Prev. 1996; 5:425-38.

Bomser J, Madhavi DL, Singletary K, Smith MAL. In vitro anticancer activity of fruit extracts from Vaccinium species. Planta Medica. 1996; 62:212-6.

Bone RA, Landrum JT, Fernandez L, Tarsist SL. Analysis of the macular pigment by HPLC: Retinal distribution and age study. Invest Ophthalmol Vis Sci. 1988; 29:843-9.

Bordia AK, Verma SK. Effect of three years treatment with garlic on the rate of re-infarction and mortality in patients with coronary artery disease. In: Garlic in Biology and Medicine: Proceedings of the First World Congress on the Health Significance of Garlic and Garlic Constituents. 1990.

Bravo L. Polyphenols: chemistry, dietary sources, metabolism, and nutritional significance. Nutr Rev. 1998; 56:317-33.

Campbell JK, Canene-Adams K, Lindshield BL, Boileau TW-M, Clinton SK, Erdman JW Jr. Tomato phytochemicals and prostate cancer risk. J Nutr. 2004; 134:3486S-92S

Caragay AB. Cancer preventive foods and ingredients. Food Technol. 1992; 46:65-8.

CARIG. Beta-carotene and the carotenoids: Beyond the intervention trials. Nutr Rev. 1996; 54:185-8.

Cassidy A, Hanley B, Lamuela-Raventus RM. Isoflavones, lignans and stilbenes - origins, metabolism and potential importance to human health. J Sci Food Agric. 2000; 80:1044-62.

Clinton SK. Lycopene: Chemistry, biology, and implications for human health and disease. Nutr Rev. 
1998; 56:35-51.

Clydesdale FM. What scientific data are necessary? Nutr Rev. 1996; 54:S195-S198.

Coulman KD, Liu Z, Hum WQ, Michaelides J, Thompson LU. Whole sesame seed is as rich a source of mammalian lignan precursors as whole flaxseed. Nutr Cancer. 2005; 52:156-65.

Crittenden RG, Playne MJ. Production, properties and applications of food-grade oligosaccharides. Trends Food Sci Technol. 1996; 7: 353-61.

Crosby GA. Lignans in food and nutrition. Food Technol. 2005; 59:32-6.

Crouse JR III, Morgan T, Terry JG, Ellis J, Vitolins M, Burke GL. A randomized trial comparing the effect of casein with that of soy protein containing varying amounts of isoflavones on plasma concentrations of lipids and lipoproteins. Arch Intern Med. 1999. 159:2070-6.

Crowell PL. Monoterpenes in breast cancer chemoprevention. Breast Cancer Res Treat. 1997; 46:191-7.

Dai Y, Luo X. Functional food in China. Nutr Rev. 1996; 54:S21-S23.

Dashwood RH. Indole-3-carbinol - Anticarcinogen or tumor promoter in Brassica vegetables. Chem Biol Interactions. 1998; 110:1-5.

DeFelice S.L. The nutraceutical revolution: its impact on food and industry R \& D. Trends Food Sci Technol. 1995; 6:59-61.

Degroot AP, Luyken R, Pikaar NA. Cholesterol lowering effect of rolled oats. Lancet. 1963; 2:303-4.

Delaquis P, Mazza G. Functional vegetable products. In: Mazza G (editor). Functional foods. Biochemical and processing aspects. Lancaster: Technomic Publishing Company, Inc.; 1998. p. 193-233.

Della Ragione F, Cucciolla V, Borriello A, Della Prieta V, Racioppi L, Soldati G, Manna C, Galletti P, Zappia V. Resveratrol arrests the cell division cycle at S/G2 phase transition. Biochem Biophys Res Commun. 1998; 250:53-58.
Department of Health and Human Services. Food labeling: Health claims, soy protein and coronary heart disease, final rule. Federal registers. FDA. 1999; 64:57700-33.

Dreosti IE. Bioactive ingredients: Antioxidants and polyphenols in tea. Nutr Rev. 1996; 54:S51-S58.

EDCC (Eye Disease Case-Control) STUDY GROUP. Antioxidant status and neovascular age-related macular degeneration. Arch Opthalmol. 1993; 111:104-9.

Ejaz S, Ejaz A, Matsuda K, Lim CW. Limonoids as cancer chemopreventive agents. J Sci Food Agric. 2006; 86:339-45.

Elson CE, Qureshi AA. Coupling of cholesterol and tumor-suppressive actions of palm oil to the impact of its minor constituents on 3-hydroxy-3-methylglutaryl coenzyme A reductase activity. Prostaglandins Leukot Essent Fatty Acids. 1995; 52:205-8.

Eitenmiller RR. Vitamin E content of fats and oils: Nutritional implications. Food Technol. 1997; 51:7881.

Erdman JW Jr, Potter SM. Soy and bone health. Soy Connection. 1997; 5:1-4.

Ernst E. Can allium vegetables prevent cancer? Phytomed. 1997; 4: 79-83.

Fahey JW, Zhang Y, Talalay P. Broccoli sprouts: An exceptionally rich source of inducers of enzymes that protect against chemical carcinogens. Proc Natl Acad Sci USA. 1997; 94:10366-72.

Fenwick, GR, Heaney RK, Mullin WJ. Glucosinolates and their breakdown products in food and food plants. Crit Rev Food Sci Nutr. 1983; 18:123-201.

Finley, J.W. Proposed criteria for assessing the efficacy of cancer reduction by plant foods enriched in carotenoids, glucosinolates, polyphenols and selenocompounds. Ann Bot. 2005; 95:1075-96.

Fleischauer AT, Poole C, Arab L. Garlic consumption and cancer prevention: meta-analysis of colorectal and stomach cancers. Am J Clin Nutr. 2000; 72:1047-52.

Fontecave M, Lepoivre M, Elleingand E, Gerez C, Guiter O. Resveratrol, a remarkable inhibitor of 
ribonucleotide reductase. FEBS Lett. 1998; 421:2779.

Frankel EN, Kanner J, German JB, Parks E, Kinsella JE. Inhibition of oxidation of human low-density lipoprotein by phenolic substances in red wine. Lancet. 1993; 341:454-7.

Freedman JE, Parker C III, Li L, Perlman JA, Frei B, Ivanov V, Deak LR, Iafrati MD, Folts JD. Select flavonoids and whole juice from purple grapes inhibit platelet function and enhance nitric oxide release . Circulation. 2001; 103:2792-8.

Gartner C, Stahl W, Sies H. Lycopene is more bioavailable from tomato paste than from fresh tomatoes. Am J Clin Nutr. 1997; 66:116-22.

Gaziano JM, Hennekens CH. The role of betacarotene in the prevention of cardiovascular disease. Ann NY Acad Sci. 1993; 691:148-55.

Gerster $\mathrm{H}$. The potential role of lycopene for human health. J Am Coll Nutr. 1997; 16:109-26.

Gibson GR, Roberfroid MB. Dietary modulation of the human colonic microbiota: Introducing the concept of prebiotics. J Nutr. 1995; 125:1401-12.

Giovannucci E. Tomatoes, tomato-based products, lycopene, and cancer: Review of the epidemiologic literature. J Natl Cancer Inst. 1999; 91:317-31.

Giovannucci E, Rimm EB, Liu Y, Stampfer MJ, Willet WC. A prospective study of tomato products, lycopene, and prostate cancer risk. J Natl Cancer Inst. 2002; 94:391-8.

Girard B, Mazza G. Functional grape and citrus products. In: Mazza G (editor). Functional foods. Biochemical and processing aspects. Lancaster: Technomic Publishing Company, Inc.; 1998. p. 139-91.

Glore SR, van Treeck D, Knehan AW, Guild M. Soluble fiber and serum lipids: a literature review. J Am Diet Assoc. 1994; 94:425-36.

Gorham J. Stilbenes and phenanthrenes. Methods in plant biochemistry, vol. 1. New York: Academic Press; 1989. p. 159-89.

Gould MN. Cancer chemoprevention and therapy by monoterpenes. Environ Hlth Perspec. 1997; 105:977-9.

Granado F, Olmedilla B, Blanco I. Nutricional and clinical relevance of lutein in human health. Br J Nutr. 2003; 90:487-502.

Green MS, Harari G. Association of serum lipoproteins and health-related habits with coffee and tea consumption in free-living subjects examined in the Israeli CORDIS study. Prev Med. 1992; 21:532-45.

Hadley CW, Miller EC, Schwartz, SJ, Clinton SK. Tomatoes, lycopene, and prostate cancer: Progress and promise. Exp Biol Med. 2002; 227:869-80.

Haller Jr ES, Miller DT, Yannuzzi LA, Willet W. Dietary carotenoids, vitamins A, C, and E, and advanced age-related macular degeneration. J Am Med Assoc. 1994; 272: 1413-20.

Handelman GJ, Dratz EA, Reay CC, van Kujik FJGM. Carotenoids in the human macula and whole retina. Invest Ophthalmol Visual Sci. 1988; 29:850-85.

Hasler CM. Functional foods: The Western perspective. Nutr Rev. 1996; 54:S6-S10.

Hasler CM. Functional foods: Their role in disease prevention and health promotion. Food Technol. 1998; 52:63-70.

Heaney RK, Fenwick GR. Natural toxins and protective factors in Brassica species, including rapeseed. Nat Toxins. 1995; 3:233-7.

Hecht SS. Chemoprevention of cancer by isothiocyanates, modifiers of carcinogen metabolism. J Nutr. 1999; 129:768S-774S.

Hertog MGL, Feskens EJM, Hollman PCH, Katan MB, Kromhout D. Dietary antioxidant flavonoids and risk of coronary heart disease: The Zutphen Elderly Study. Lancet. 1993; 342: 1007-11.

Hicks KB, Moreau RA. Phytosterols and phytostanols: Functional food cholesterol busters. Food Technol. 2001; 55:63-7.

Hodgson JM, Puddey IB, Beilin LJ, Mori TA, Croft KD. Supplementation with isoflavonoid phytoestrogens does not alter serum lipid concentrations: A 
randomized controlled trial in humans. J Nutr. 1998; 128:728-32.

Hollman PCH, Arts ICW. Flavonols, flavones and flavanols - nature, occurrence and dietary burden. J Sci Food Agric. 2000; 80:1081-93.

Hollman PCH, Venema DP. The content of the potentially anticarcinogenic ellagic acid in plant foods. In: Waldron KW, Johnson IT, Fenwick GR (editors). Food and cancer prevention: Chemical and biological aspects. Cambridge, England: The Royal Society of Chemistry; 1993. p. 202-8.

Howell AB, Versa N, der Marderosian A, Foo LY. Inhibition of the adherence of P-fimbriated Escherichia coli to uroepithelial-cell surfaces by proanthocyanindin extracts from cranberries. New Eng J Med. 1998; 339:1085-6.

Huang M-T, Ferraro T, Ho C-T. Cancer chemoprevention by phytochemicals in fruits and vegetables: An overview. In: Huang M-T, Osawa T, Ho C-T, Rosen RT (editors). Food phytochemicals for cancer prevention I. Fruits and vegetables. Washington DC: American Chemical Society; 1994. p. 2-16.

Inks S, Mathews R. Oatmeal and oat-bran: Heart healthy benefits and more. In: Yalpani M (editor). New Technologies for healthy foods and nutraceuticals. Shrewsburry, Massachusetts: ATL Press; 1997.

Isaachson JL, Moser M, Stein EA, Dudley K, Davey JA, Liskov E, Black HR. Garlic powder and plasma lipids and lipoproteins: A multicenter, randomized, placebo-controlled trial. Arch Intern Med. 1998; 158:1189-94.

Jang M, Cai L, Udeani GO, Slowing KV, Thomas CF, Beecher CWW, Fong HHS, Farnsworth NR, Kinghorn AD, Mehta RG, Moon RC, Pezzuto JM. Cancer chemopreventive activity of resveratrol, a natural product derived from grapes. Science . 1997; 275:218-20.

Jones PJ, Raeini-Sarjaz M. Plant sterols and derivatives: The current spread of results. Nutr Rev. 2001; 59:214.

Kaneko R, Tsuchiya T. New compound in rice bran and germ oils. J Chem Soc Jpn. 1954. 57:526.
Kaur C, Kapoor HC. Antioxidants in fruits and vegetables - the millenium's health. Int J Food Sci Technol. 2001; 36:703-25.

Kohlmeier L, Hastings SB. Epidemiologic evidence of a role of carotenoids in cardiovascular disease prevention. Am J Clin Nutr. 1995; 62:1370S-6S.

Kohlmeier L, Kark JD, Gomez-Garcia E, Martin BC, Steck SE, Kardinaal AFM, Ringstad J, Thamm M, Masaev V, Riemersma R, Martin-Moreno JM, Huttunen JK, Kok FJ. Lycopene and myocardial infarction risk in the EURAMIC Study. Am J Epidemiol. 1997a; 146:618-26.

Kohlmeier L, Weterings KGC, Steck S, Kok FJ. Tea and cancer prevention: An evaluation of the epidemiologic literature. Nutr Cancer. 1997b; 27:1-13.

Komiyama K, Hayashi M, Cha S, Yamaoka M. Antitumor and antioxidant activity of tocotrienols. In: Ong ASH, Packer L (editors). Lipid-soluble antioxidants: Biochemistry and clinical applications. Basel, Switzerland: Birkhauser Verlag; 1992. p. 1529.

Kono S, Shinchi K, Ikeda N, Yanai F, Imanishi K. Green tea consumption and serum lipid profiles: A cross-sectional study in Northern Kyushu, Japan. Prev Med. 1992; 21:526-31.

Krinsky NI. Actions of carotenoids in biological systems. Annu Rev Nutr. 1993; 13:561-87.

Krinsky NI, Johnson EJ. Carotenoid actions and their relation to health and disease. Mol Aspects Med. 2005; 26:459-516.

Kris-Etherton PM, Hecker KD, Bonanome A, Coval SM, Binkoski AE, Hilpert KF, Griel AE, Etherton TD. Bioactive compounds in foods: Their role in the prevention of cardiovascular disease and cancer. Am J Med. 2002; 113:71S-88S.

Kuroda Y, Hara Y. Antimutagenic and anticarcinogenic activity of tea polyphenols. Mutation Res. 1999; 436:69-97.

Laplaud PM, Lelubre A, Chapman MJ. Antioxidant action of Vaccinium myrtillus extract on human low density lipoproteins in vitro: Initial observations. Fundam Clin Pharmacol. 1997; 11:35-40. 
Law MR, Morris JK. By how much does fruit and vegetable consumption reduce the risk of ischaemic heart disease? Eur J Clin Nutr. 1998; 52:549-56.

Lia A, Andersson H, Mekki N, Juhel C, Senft M, Lairon D. Postprandial lipemia in relation to sterol and fat excretion in ileostomy subjects given oat-bran and wheat with meals. Am J Clin Nutr. 1997; 66:357-65.

Lin X-Y, Lin JZ, Milner JA. Dietary garlic suppresses DNA adducts caused by $\mathrm{N}$-nitroso compounds. Carcinogenesis. 1994; 15:349-52.

Mayne ST. Beta-carotene, carotenoids, and disease prevention in humans. FASEB J. 1996; 10:690-701.

Mei X, Wang MC, Xu HX, Pan P, Gao CY, Han N, Fu MY. Garlic and gastric cancer - the effect of garlic on nitrite and nitrate in gastric juice. Acta Nutr Sinica. 1982; 4:53-8.

Mei X, Lin X, Liu J, Song P, Hu J, Liong X. The blocking effect of garlic on the formation of $\mathrm{N}$ nitrosoproline in humans. Acta Nutrimenta Sinica. 1989; 11:141-5.

Messina M, Barnes S. The role of soy products in reducing risk of cancer. J Natl Cancer Inst. 1991; 83:541-6.

Michnovicz JJ, Bradlow HL. Altered estrogen metabolism and excretion in humans following consumption of indole carbinol. Nutr Cancer. 1991; 16:59-66.

Miettinen TA. Phytosterols - what plant breeders should focus on. J Sci Food Agric. 2001; 81: 895903.

Milner JA. Preclinical perspectives on garlic and cancer. J Nutr. 2006; 136:827S-31S.

Mithen RF, Dekker M, Verkerk R, Rabot S, Johnson IT. The nutritional significance, biosynthesis and bioavailability of glucosinolates in human foods. J Sci Food Agric. 2000; 80:967-84.

Moeller SM, Jacques PF, Blumberg JB. The potential role of dietary xanthophylls in cataract and agerelated macular degeneration. J Am Coll Nutr. 2000; 19:522S-7S.
Morazzoni P, Bombardelli E. Vaccinium myrtillus. Fitoterapia. 1996; 67:3-30.

Morazzoni P, Magistretti MJ. Activity of myrtocyan, anthocyanoside complex from Vaccinium myrtillus (VMA), on platelet aggregation and adhesiveness. Fitoterapia. 1990; 61:13-21.

Moreau RA, Powell MJ, Hicks KB. Extraction and quantitative analysis of oil from commercial corn fiber. J Agric Food Chem. 1996; 44:2149-54.

Murphy PA, Hendrich S. Phytoestrogens in foods. Adv Food Nutr Res. 2002; 44:195-246.

Nagata C, Takatsuka N, Kurisu Y, Shimizu H. Decreased serum total cholesterol is associated with high intake of soy products in Japanese men and women. J Nutr. 1998; 128:209-13.

Namiki M. Antimutagen and anticarcinogen research in Japan. In: Huang M-T, Osawa T, Ho C-T, Rosen RT (editors). Food phytochemicals for cancer prevention I. Fruits and vegetables. Washington DC: American Chemical Society; 1994. p. 65-81.

Ness AR, Powles JW. Fruit and vegetables, and cardiovascular disease: A review. Int J Epidemiol. 1997; 26:1-13.

Nestle M. Broccoli sprouts in cancer prevention. Nutr Rev. 1998; 56:127-30.

Nestle PJ, Yamahita T, Sasahara T, Pomeroy S, Dart A, Komesaroff P, Owen A, Abbey M. Soy isoflavones improve systemic arterial compliance but not plasma lipids in menopausal and premenopausal women. Arterioscler Thromb Vasc Biol. 1997; 17: 3392-8.

Ofek I, Goldhar J, Sharon N. Anti-Escherichia coli adhesion activity of cranberry and blueberry juices. In: Kahane S, Ofek I (editors). Toward anti-adhesion therapy for microbial diseases. New York: Plenum Press; 1996. p. 179-83.

Oguni I, Chen SJ, Lin PZ, Hara Y. Protection against cancer risk by Japanese green tea. Prev Med. 1992; 21:332-3

Olson JA. Carotenoids and human health. Arch Latinoamer Nutr. 1999; 49:7S-11S. 
Omenn GS, Goodman GE, Thornquist MD, Balmes J, Cullen MR, Glass A, Keogh JP, Meysken FL Jr, Valanis B, William JH Jr, Barnhart S, Hammer S. Effects of a combination of beta-carotene and vitamin A on lung cancer and cardiovascular disease. New Engl. J. Med. 1996; 334: 1150-5.

Oomah BD. Flaxseed as a functional food source. J Sci Food Agric. 2001; 81:889-94.

Oomah BD, Mazza G. Health benefits of phytochemicals from selected Canadians crops. Trends Food Sci Technol. 1999; 10:193-8.

Palace VP, Khaper N, Qin Q, Singal PK. Antioxidant potentials of vitamin $A$ and carotenoids and their relevance to heart disease. Free Radic Biol Med. 1999; 26:746-61.

Palozza P, Krinsky NI. Antioxidant effects of carotenoids in vivo and in vitro: An overview. Meth Enzymol. 1992; 213:403-20.

Parker RA, Pearce BC, Clark RW, Gordon DA, Wright JJK. Tocotrienols regulate cholesterol production in mammalian cells by post-transcriptional suppression of 3-hydroxy-3-methylglutaryl-coenzyme A reductase. J Biol Chem. 1993; 268:11230-8.

Parr AJ, Bolwell GP. Phenols in the plant and in man. The potential of possible nutritional enhancement of the diet by modifying the phenol content or profile. J Sci Food Agric. 2000; 80:985-1012.

Petesch BL, Sumiyoshi H. Recent advances on the nutritional benefits accompanying the use of garlic as a supplement. Trends Food Sci Technol. 1999; 9:415-8.

Piironen GW, Price KR, Rhodes MJC, Willianson G. Tocopherols and tocotrienols in Finnish foods: Vegetables, fruits and berries. J Agric Food Chem. 1986; 34: 742-6.

Piironen V, Lindsay DG, Miettinen TA, Toivo J, Lampi A-M. Plant sterols: Biosynthesis, biological function and their importance to human health. J Sci Food Agric. 2000; 80:939-66.

Potter SM. Soy protein and cardiovascular disease: The impact of bioactive components in soy. Nutr Rev. 1998; 56:231-5.
Price KR, Fenwick GR. Naturally occurring oestrogens in foods- a review. Food Addit Contam. 1985; 2:73-106.

Prior RL, Cao G. Antioxidant phytochemicals in fruits and vegetables: Diet and health implications. Hort Sci. 2000; 35:588-92.

Qureshi AA, Pearce BC, Nor RM, Gapor A, Peterson DM, Elson CE. $\alpha$-Tocopherol attenuates the impact of tocotrienol on hepatic 3-hydroxy-3-methylglutaryl coenzyme A reductase activity. J Nutr. 1996; 126:38994.

Rao AV, Agarwal S. Role of lycopene as antioxidant carotenoid in the prevention of chronic diseases: a review. Nutr Res. 1999; 19:305-23.

Rahman K, Lowe GM. Garlic and cardiovascular disease: A critical review. J Nutr. 2006; 136:736S$740 S$.

Renaud S, de Lorgeril M. Wine, alcohol, platelets, and the French paradox for coronary heart disease. The Lancet. 1992; 339:1523-6.

Rice-Evans CA, Miller NJ, Paganga G. Structureantioxidant activity relationship of flavonoids and phenolic acids. Free Radic Biol Med. 1996; 20:93356.

Ripple GH, Gould MN, Stewart JA, Tutsch, KD, Arzoomanian RZ, Alberti D, Feierabend C, Pomplun M, Wilding G, Bailey HH. Phase I clinical trial of perillyl alcohol administered daily. Clin Cancer Res. 1998; 4:1159-64.

Ripsin CM, Keenan JM, Jacobs DR, Elmer PJ, Welch RR. Oat products and lipid lowering. J Am Med Assoc. 1992; 267:3317-25.

Rissanen T, Voutilainen S, Nyyssönen K, Salonen JT. Lycopene, atherosclerosis and coronary heart disease. Exp Biol Med. 2002; 227:900-7.

Roberfroid MB. Functional effects of food components and the gastrointestinal system: Chicory fructooligosaccharides. Nutr Rev. 1996; 54:S38-S42.

Rock CL, Lovalvo JL, Emenhiser C, Ruffin MT, Flatt SW \& Schwart SJ. Bioavailability of $\beta$-carotene is lower in raw than in processed carrots and spinach 
in women. J Nutr. 1998; 128:913-6.

Rodriguez-Amaya DB. Nature and distribution of carotenoids in foods. In: Charalambous G (editor). Shelf-life studies of foods and beverages. Chemical, biological, physical and nutritional aspects. Amsterdam: Elsevier Science Publishers; 1993. p. 547-89.

Rodriguez-Amaya DB. Latin American food sources of carotenoids. Arch Latinoamer Nutr. 1999; 49: 74S$84 \mathrm{~S}$.

Rotondo S, de Gaetano G. Protection from cardiovascular disease by wine and its derived products. Epidemiological evidence and biological mechanisms. World Rev Nutr Diet. 2000; 87:90-113.

Schneeman BO. Linking agricultural production and human nutrition. J Sci Food Agric. 2000; 81:3-9.

Seddon JM, Ajani UA, Sperduto RD, Hiller R, Blair N, Burton TC, Ferber MD, Gragoudas ES, Haller J, Miller DT, Yannuzzi LA, Willet W. Dietary carotenoids, vitamins A, C, and E, and advanced agerelated macular degeneration. J Am Med Assoc. 1994; 272: 1413-20.

Serbinova EA, Tsuchiya M, Goth S, Kagan VE, Packer L. Antioxidant action of $\alpha$-tocopherol and $\alpha$-tocotrienol in membranes. In: Packer L, Fuchs J (editors). Vitamin E in health and disease. New York: Marcel Dekker; 1993. p. 235-43.

Sies H, Stahl W. Lycopene: Antioxidant and biological effects and its bioavailability in the human. Proc Soc Exp Biol Med. 1998; 218:121-4.

Silagy C, Neil A. Garlic as a lipid-lowering agent - a meta-analysis. J Royal Coll Physicians Lond. 1994; 28:39-45.

Sivam GP, Lampe JW, Ulness B, Swanzy SR, Potter JD. Helicobacter pylori - in vitro susceptibility to garlic (Allium sativum) extract. Nutr Cancer. 1997; 27:11821.

Stacewicz-Sapuntzakis M, Bowen PE. Role of lycopene and tomato products in prostate health. Biochim Biophy Acta. 2005; 1740:202-5.

Stahl W, Ale-Agha N, Polidori MC. Non-antioxidant properties of carotenoids. Biol Chem. 2002; 383:553-8.
Stahl W, Sies H. Bioactivity and protective effects of natural carotenoids. Biochim Biophys Acta. 2005; 1740:101-7.

Steinmetz KA, Kushi H, Bostick RM, Folsom AR, Potter JD. Vegetables, fruit, and colon cancer in the Iowa Women's Health Study. Am J Epidemiol. 1994; 139:1-15.

Steinmetz KA, Potter JD. Vegetables, fruit, and cancer prevention: A review. J Am Diet Assoc. 1996; 96:102739

Stensvold I, Tverdal A, Solvoll K, Foss OP. Tea consumption, relationship to cholesterol, blood pressure and coronary artery disease mortality. Prev Med. 1992; 21:546-53.

Stoewsand GS. Bioactive organosulfur phytochemicals in Brassica oleracea vegetable - A review. Food Chem Toxicol. 1995; 33:537-43.

Sun NJ, Woo SH, Cassady JM, Snapka RM. DNApolymerase and topoisomerase-II inhibitors from Psoralea coryfolia J Nat Prod. 1998; 61:362-6.

Talalay P, Fahey JW. Phytochemicals from cruciferous plants protect against cancer by modulating carcinogen metabolism. J Nutr. 2001; 131:3027S-33S.

Tan B. Palm carotenoids, tocopherols and tocotrienols. J Am Oil Chem Soc. 1989; 66:770-6.

Teissedre PL, Frankel EN, Waterhouse AL, Pelez E, German JB. Inhibition of in vitro human LDL oxidase by phenolic antioxidants from grapes and wines. J Sci Food Agric. 1996; 70:55-61.

Thebaudin JY, Febvre AC, Harrington M, Bourgeois CM. Dietary fibres: Nutritional and technological interest. Trends Food Sci Technol. 1997; 8:41-8.

Thomas PR, Earl, R (editors). Enhancing the food supply. In: Opportunities in the nutrition and food sciences. Washington, DC: National Academy Press; 1994. p. $98-142$.

Thompson LU, Robb P, Serraino M, Cheung E. Mammalian lignan production from various foods. Nutr Cancer. 1991; 16:43-52.

Tijburg LBM, Mattern T, Folts JD, Weisgerber UM, 
Katan MB. Tea flavonoids and cardiovascular diseases: A review. Crit Rev Food Sci Nutr. 1997; 37: 771-85.

Torronen R. Flavonols and ellagic acid in berries. Recent Adv Agric Food Chem. 2000; 1:31-7.

Van den Berg H, Faulks R, Fernando Granado H, Hirschberg J, Olmedila B, Sandmann G, Southon S, Stahl W. The potential for the improvement of carotenoid levels in foods and the likely systemic effects. J Sci Food Agric. 2000; 80:880-912.

Verhoeven DTH, Goldbohm RA, van Poppel G, Verhagen $\mathrm{H}$, van den Brandt PA. Epidemiological studies on brassica vegetables and cancer risk. Cancer Epidemiol Biomark Prev. 1996; 5:733-48.

Verhoeven DTH, Verhagen H, Goldbohm RA, van den Brandt PA, van Poppel G. A review of mechanisms underlying carcinogenicity by brassica vegetables. Chem Bio Interactions. 1997; 103:79-129.

Voragen AGJ. Technological aspects of functional food-related carbohydrates. Trends Food Sci Technol. 1998; 9:328-35.

Wang H, Cao G, Prior RL. Oxygen radical absorbing capacity of anthocyanin. J Agric Food Chem. 1997; 45:3425-31

Wang H, Provan GJ, Helliwell K. Tea flavonoids: Their functions, utilisation and analysis. Trends Food Sci Technol. 2000; 11:152-60.

Warshafsky S, Kamer RS, Sivak SL. Effect of garlic on total serum cholesterol. A meta-analysis. Ann Intern Med. 1993; 119:599-605.

Wertz K, Siler U, Goralczyk R. Lycopene: modes of action to promote prostate health. Arch Biochem Biophys. 2004; 430: 127-34.
Wollin SD, Jones PJH. Alcohol, red wine and cardiovascular disease. J Nutr. 2001; 131:1401-4.

Wong GYC, Bradlow L, Sepkovic D, Mehl S, Mailman J, Osborne MP. Dose-ranging study of indole-3carbinol for breast cancer prevention. J Cell Biochem. 1998; 22 (Suppl 28-29):111-6.

World Cancer Research Fund. Food, nutrition and the prevention of cancer: A global perspective. Washington DC: American Institute for Cancer Research; 1997.

Yang CS, Landau JM, Huang M-T, Newmark HL. Inhibition of carcinogenesis by dietary polyphenolic compounds. Annu Rev Nutr. 2001; 21:381-406.

You W-C, Blot WJ, Chang Y-S, Ershow AG, Yang, Z-T, An Q, Henderson BE, Fraumeni JF, Wang T-G. Allium vegetables and reduced risk of stomach cancer. J Natl Cancer Inst. 1989; 81:162-4.

Yu BP. Aging and oxidative stress: Modulation by dietary restriction. Free Radic Biol Med. 1996; 21:651-68.

Zhang Y, Talalay P, Cho C-G, Posner GH. A major inducer of anticarcinogenic protective enzymes from broccoli: Isolation and elucidation of structure. Proc Natl Acad Sci USA. 1992; 89:2399-403.

Ziegler RG. Vegetables, fruits, and carotenoids and the risk of cancer. Am J Clin Nutr. 1991; 53:251S-9S.

Ziegler RG, Colavito, EA, Hartge, P, McAdams MJ, Schoenberg JB, Mason TJ, Fraumeni JF Jr. Importance of alpha-carotene, beta-carotene, and other phytochemicals in the etiology of lung cancer. J Natl Cancer Inst. 1996; 88:612-5. 